\title{
Strategic outsourcing? The Philips case in the LCD TV Market
}

\author{
Luiz Carlos Di Serio',Robson Dantas Bento², Guilherme Silveira Martins³, André Luis de Moura Castro Duarte ${ }^{4}$
}

\begin{abstract}
This work seeks to assess the outsourcing process adopted by Philips for producing LCD televisions. The authors used the Resource-based Theory and the Transaction Cost Theory for analyzing the case. Based on industry data and interviews with ten of the company's senior executives, this study sought to understand how the decision making process was carried out and how it affected the company's activities in the field of LCD televisions. Philips has lost its competitiveness in the Brazilian market - it went from being the leader in 2006 to fourth place in 2009, both as far as regards its sales volume and value. The executives pointed out that the LCD panel is an important resource and that its supply by third parties represented a high transaction cost. The results illustrate the complementarity that exists between the RBT and TCT theories in a competitive environment that has few players.
\end{abstract}

Keywords: Outsourcing; resource-based theory; transaction cost theory; case study.

\footnotetext{
I PhD. São Paulo Business Administration School of Fundação Getulio Vargas (FGV-EAESP), Department of Production and Industrial Operations Administration. Av. Nove de Julho 2029, Bela Vista, São Paulo, SP, 0 I 3 I 3-902, Brazil. Tel: +55 (I I) 3799-7780.

E-mail: luiz.diserio@fgv.br

${ }_{2}$ MsC. São Paulo Business Administration School of Fundação Getulio Vargas (FGV-EAESP), Department of Production and Industrial Operations Administration. Av. Nove de Julho 2029, Bela Vista, São Paulo, SP, 0 I 3 I 3-902, Brazil. Tel: +55 (I I) 3799-7780.

E-mail: rdantasbento@hotmail.com

${ }^{3}$ Candidate. São Paulo Business Administration School of Fundação Getulio Vargas (FGV-EAESP), Department of Production and Industrial Operations Administration. Av. Nove de Julho 2029, Bela Vista, São Paulo, SP, 0 I 3 I 3-902, Brazil. Tel: +55 (I I) $3799-7780$. E-mail: mr.gsmartins@hotmail.com ${ }^{4}$ PhD. INSPER - Education and Research Institute, Brazil. Rua Quatá, 300 - Vila Olímpia, São Paulo, SP, 04546-042, Brazil. Tel +55 (I I) 4504-2400. Email: andrelcmd@insper.edu.br
} 


\section{Introduction}

The make-or-buy decision is one of the most important and uncertain in supply chain management. Although it is possible in literature to find a wide range of studies in the most diverse of sectors on how to make a decision about whether to make or buy (Drtina, 1994; Quinn and Hilmer, 1994; Fine and Whitney, 1996, Chesbrough and Teece, 1996; Canez, Probert and Plattz, 2000), there is no consensus between authors on the best decision model. These models differ in their results when applied at different moments in time to different sectors or areas of the company.

There is evidence that companies, when making the decision to outsource an activity, sometimes focus on short-term improvements, particularly on costs, in detriment to the development of capabilities over the long term. Empirical investigations systematically indicate that one of the main reasons for outsourcing the production of a finished product is to reduce the cost of goods sold (Bardhan, Mithas and Lin, 2007; Gray, Roth and Tomlin, 2008, Woollacott, 2006).There is a tendency to base outsourcing decisions solely on current performance, rather than comparisons of the potential improvements available to the firm in the future (Doig, Ritter, Speckhals and Woolson, 200I). Novak and Stern (2008) empirically observed that outsourcing can be associated with higher levels of performance in the short term, but lower levels of performance improvement over the medium and long terms. According to the Resource-based Theory (RBT) of the company (Barney, 1999), today's decisions related to production can significantly affect the production capability of the company in the future.

To meet the challenges arising from the competitive scene in which they operate, companies follow different models of vertical integration, depending on their strategy. Highly verticalized chains generate advantages, such as lower transaction costs, less exposure to supply variability, quicker response times to demand variability, greater autonomy with regard to own technology, and the like. In contrast, less verticalized models allow for greater focus on the product, lower levels of investment in assets and lower production costs. Therefore, the extremely important strategic decisions are those about which operations should be kept within the boundaries of the company and which will be performed by suppliers.
The problem raised in this work involves the case of multinational company, Philips. From 2006 to 2009, the company lost competitiveness in its LCD (Liquid Crystal Display) TV business: it went from being the leader in sales to fourth placed, according to consulting firm GFK (Growth from Knowledge) (2009). This study sought to identify the relationship that exists between loss of competitiveness and the decision to outsource the production of LCD panels, its main input. The authors used Resource-based Theory (RBT) and Transaction Cost Theory (TCT) as their theoretical framework for analyzing the case. Based on sector data and interviews with ten senior company executives, this study sought to understand the decision-making process and how it affected the company's activities in the LCD TV sector. In addition to being a potential case to be used in courses on Operations Management and Supply Chains, the article's approach demonstrates the applicability of jointly exploring RBT and TCT in the analysis of outsourcing processes.

The article is organized into five sections, beginning with this introduction. Then the concepts that form the basis of the analyses of this study are set out. The third section deals with the methodological procedures adopted by the researchers. Then there is an analysis of Philips, with information about its chain and the perception of its executives on the outsourcing process. The fifth and last section discusses the final considerations of the work and makes suggestions for future research.

\section{Theoretical Basis}

The make-or-buy decision covers various alternatives and is not simply limited to making or buying. There is a relatively broad range of alternative possibilities, among which the following are worth highlighting: producing internally without investment, producing internally with investment, integrating (vertically or horizontally), partially integrating, quasi-integrating (developing partnerships or strategic alliances, licensing, franchising), outsourcing, de-verticalizing and divesting (Porter, 1980; Stuckey and White, 1993; Wright, Kroll and Parnell, 1998; Fine and Whitney, 1996).

The criteria most commonly cited in literature fit the three aspects of this issue, namely: the administrative approach (strategy), economic approach (transaction cost) and financial approach. In the first case, the main criteria relate 
to suppliers (external focus) and competences (internal focus). In the other approaches, the level of control, the risks that lead to company vulnerability and the total cost involved in the decision are also frequently cited criteria. To analyze the Philips case, two complementary approaches were selected: RBT and the Transaction Cost Theory, as set out in the following topics.

\section{I Resource-based Theory (RBT)}

The Resource-based Theory sees the firm as a set of resources and capabilities. It claims that the unique combination of a set of complementary resources and specialized capabilities (which are heterogeneous within an industry, are scarce, durable, not easily negotiated and difficult to imitate), can lead to value creation (Penrose, 1959; Wernerfelt, 1984; Barney, 1991; Peteraf, 1993; Amit and Schoemaker, 1993). The assumption is that even in equilibrium, companies may differ in terms of the resources and capabilities they control, and that such asymmetric companies can coexist until some change or exogenous shock occurs. RBT, therefore, claims that the company's exclusive package of resources and capabilities can lead to superior performance.

The resources of a firm are valuable if, and only if, they reduce company costs or increase its revenue relative to what would have been the case if the company did not have such resources (Barney, 1997). Although RBT literature often concerns itself with questions of value appropriation and sustainability of competitive advantage (e.g. Barney, 1991), an extension of RBT, the dynamic capabilities approach (Teece, Pisano and Shuen, 1997), explores how valuable the resources built up and acquired over time can be. Dynamic capabilities are rooted in a company's managerial and organizational processes, such as those used for coordinating, integrating, reconfiguring, transforming (Teece et al., 1997, Eisenhardt and Martin, 2000) or for learning (Lei, Hitt and Bettis, 1996).

From this perspective, RBT is important in the study of outsourcing processes, because the superior performance achieved by a firm in organizational activities relative to the competition would explain why certain activities are developed internally. Langlois and Robertson (1995) explain that by the methods of this theory the organization's boundaries can be determined, by comparing its internal capabilities with the capabilities of its competitors. Therefore, outsourcing decisions are influenced by the skill a company has for investing in developing a certain capability that will sustain a position of superior performance vis-à-vis its competitor.

\subsection{Transaction cost theory (TCT)}

The central issue addressed by the Transaction Cost Theory (TCT) is why companies choose to internalize operations that could be carried out in markets (Coase, 1937). The main theoretical framework was developed by Williamson (1975, 1979, 1983). He suggests that a transaction occurs when a good or service is transferred by means of a technologically separable interface; one processing and transformation stage ends and another begins (Williamson, 1983). Williamson identified limited rationality, coupled with uncertainty, complexity, asymmetric information and opportunism in a small number of situations, as the conditioner of the inefficiencies that can arise in transactions; these inefficiencies may vary according to the governance mechanism adopted (Williamson, 1975).

Governance is the mechanism whereby companies manage economic exchange; in other words, this is a way in which organizations decide to relate to one another. According to Barney (1999), these ways can be grouped into three categories:

Market governance - used by companies to manage financial exchanges when they interact sporadically with other organizations in the market. This type of relationship happens, for example, when a company in the electronic sector buys standardized electronic components from a component distributor. Such procedures usually have lower transaction costs;

Intermediate governance - employed when companies develop complex agreements and other forms of strategic alliance, including joint ventures, for carrying out financial exchanges. For example, retail companies use intermediate governance to obtain products through the negotiation of long-term supply agreements. These negotiations often establish more advanced forms of relationship and customer and supplier enter into more collaborative processes, establishing joint systems for exchanging information, such as Electronic Data Interchange (EDI), or they even transfer critical operations closer to the customer's top management; 
Hierarchical governance - used when companies bring exchanges within their boundaries and operate in a verticalized way. For example, a manufacturing company uses hierarchical governance when it owns and operates a plant that supplies products that it itself sells. A retailer uses hierarchical governance when it operates a chain comprising both the sale and distribution of the products it sells. In both cases, the parties involved in the exchanges do not operate independently. On the contrary, the third party involved in this operation is the manager itself, which has the right to determine the actions and decisions in the links of the chain.

As suggested by Mclvor (2008) and Holcomb and Hitt (2007), analysis of the factors that interfere in the transaction, when related to the categories of governance, help in decisionmaking involving outsourcing processes. Such decisions are essentially based on an economic analysis and seek to reduce production costs and maximize profit in operations.

Therefore, TCT is essentially concerned with explaining the choice of the most efficient form of governance in a given transaction that is incorporated into a specific economic context. The critical dimensions of the operations that influence this choice are uncertainty, exchange frequency and the specific nature of the assets that allow the exchange (Klein, Crawford and Alchian, 1978; Williamson, 1979).

Transaction costs include the costs of planning, adapting, implementing, monitoring and concluding tasks (Williamson, 1983). TCT identifies the efficiency of the transaction as being an important source of value, since greater efficiency reduces costs. It therefore suggests that value creation can derive mainly from the alleviation of uncertainty, complexity and information asymmetry (Williamson, 1975). Furthermore, reputation, trust and transactional experience can reduce the cost of idiosyncratic exchanges between companies (Williamson, 1979, 1983). Organizations that economize transaction costs tend to extract greater value from the transactions.

However, TCT's emphasis on efficiency (i.e. cost) can divert attention away from other fundamental sources of value, such as innovation and the reconfiguration of resources (Ghosh and Moran, 1996). In addition, the theory concentrates on minimizing costs in each transaction agent and neglects the interdependence between the parties and the opportunities for jointly maximizing value (Zajac and Olsen, 1993). Finally, Williamson (1983) defines a transaction as a discrete event; it is valuable in itself, since it reflects the search for a more efficient form of governance and it can, therefore, be a source of gain in transactional efficiency.

So, this study sought to analyze the outsourcing process from the perspective of RBT, with a focus on the firm's strategy, and the Transaction Cost Theory (TCT), which analyzes the relationship in the chain.

\section{Methodological Definitions}

The research was conducted in two phases. First, we sought to understand the configuration of the LCD TV chain. The study was descriptive in character and its data source was sector reports and websites that specialize in the industry. The researchers concentrated on collecting this information in order to provide evidence of the supply and production strategies of the main players in the sector.

In possession of the configuration of the LCD TV chain, the researchers then collected primary data. This phase is explanatory in nature, because it intends to identify whether the outsourcing process for the production of LCD panels was related to Philips' loss of competitiveness in the sector. The data were collected by means of interviews with executives from Philips, who either had or still have a large degree of involvement in the management of the television business or the outsourcing process. The following people were interviewed:

I. The industrial director of the Philips television plant in Manaus (Amazonas, Brazil);

2. The production manager of the Philips television plant in Manaus (Amazonas, Brazil);

3. The purchasing manager of the Philips television plant in Manaus (Amazonas, Brazil);

4. The marketing and product line manager of Philips televisions in Brazil;

5. The global planning and purchasing manager for Philips televisions in Amsterdam (Netherlands);

6. The global planner of Philips LCD panels with supplier, LGD; 7. The Vice President of Philips Telecom Brazil, responsible for the television business at the time of the outsourcing of the production of LCD panels;

8. The television project manager at the time of the outsourcing of the production of LCD panels;

9. The general manager for the introduction of new products in Latin America;

10. The financial manager for the television business in Brazil. 
The interviews were conducted by telephone. The script was constructed in a semi-structured way, based on the dimensions of the RBT and TCT models, as outlined in the previous section. These data were treated qualitatively, using the content analysis technique. The content of the interviewees' answers was categorized according to the dimensions mentioned above. In this way, it was possible to capture the perception of the Philips executives with regard to the LCD TV outsourcing process.

The choice of a case study strategy for studying the phenomenon is supported by two pillars: (i) the fact that studies on the benefits of the outsourcing process are inconclusive. Many studies have found positive effects, but others question whether they persist over the long term (Novak and Stern, 2008). A qualitative approach, therefore, that goes into a specific case in more depth, might raise relevant issues for future studies on the theme; (ii) the consumer electronics industry, especially that of LCD televisions, is dominated by a few major players, which makes the Philips case study representative for the sector, although the results cannot be generalized.

\section{Case Analysis}

The results of the study are presented and discussed in this section. It is structured into two topics. The first analyzes the LCD televisions chain and the second specifically analyzes the Philips case based on the theories of RBT and TCT.

\section{I Configuration of the LCD TV chain}

The LCD panel is characterized by being thin and flat, and electronically it is used to transmit text, pictures and moving images and can be used in computer monitors, digital cameras, cell phones, watches, calculators, instrument panels, aircraft, automobiles etc. Among its main features are its light weight, portability, strength, large size and ease of use. LCD technology, in addition to providing a higher quality image, has a lower manufacturing cost than previous technology (CRT). Therefore, LCD panels rapidly gained ground in the electronics industry.
New components that were specially planned for a specific LCD panel will be associated with the end product (the LCD television). This is an important factor in this work, because although the market has various suppliers, long-term associations with suppliers are important so that the specific panel for the project can be obtained. In practical terms, the panel is known as hardware (physical equipment) which, when associated with other hardware, will form the LCD television. The latter, in its turn, has certain characteristics that are capable of receiving certain software (program) that will make use of the physical components to generate images. This fact means that the LCD panel is a component that is specifically supplied; so the buyer will need to have the correct generation for its purpose. And according to Philips, in 2009 the LCD panel represented $70 \%$, on average, of the final cost of the product. That's the main reasons why the market governance structures don't exist.

\section{Configuration of the supply chain}

LCD panel makers are located in China, Japan, Korea and Taiwan (Witsview, 2009). The three main brands operating in the Brazilian market along with Philips are LG, Samsung and Sony. LG and Samsung sought forms of hierarchical governance, by verticalizing in order to control the whole value chain. Philips and Sony, on the other hand, sought intermediate forms of governance when they associated with the first two companies to form joint ventures. Figures $I$ and 2 show how the companies organized themselves to operate in the market.

Sony owns $50 \%$ of the investment in panel production together with Samsung, with a reasonable control over costs and priorities as to supplies. It is assumed that there is no significant difference in the cost of the component between Sony and Samsung and that there are not even any different priorities with regard to volumes. This cost fact is important for determining competitiveness in a sector characterized by aggressive pricing strategies. On the other hand, it is worth pointing out that all the components necessary for the production of the LCD panel come from Samsung itself. In terms of the Transaction Cost Theory, in addition to the specific nature of the asset in question, opportunistic behavior by Samsung, such as the non-supply of panels or a prohibitive pricing strategy, for example, could remove Sony from this market. Naturally, the partnership is based on contractual guarantees. 


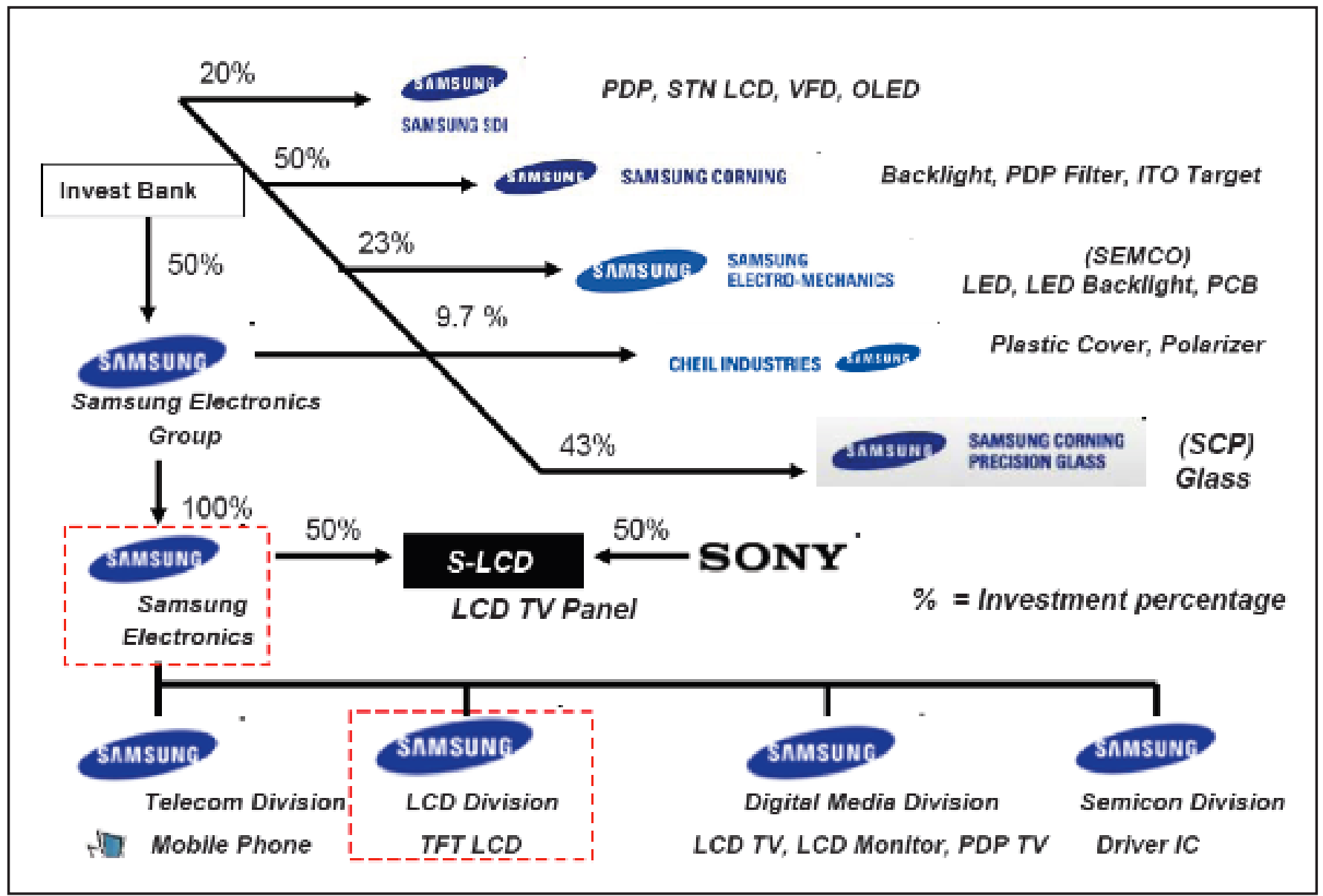

Figure I: Samsung and Sony partnership/ Source: Display Search (2008)

According to Chang (2008), Sony defended its choice of this model because it did not believe that LCD technology would last long as a solution for televisions. Philips sought a similar solution and teamed up with its rival LG, forming LG Philips Displays (LGD). This company also guaranteed it the volume and control needed to operate in the market. However, over the years the company reduced its stake in LGD, which might have implications when it comes to guaranteeing volume and reduces the company's control over the flow of materials. Figure 2 shows the level of vertical integration of LG, the supplier of panels to Philips. In this transaction, Philips has no equality in the allocation of supplies, because the control it exercises is limited to its participation in the structure. Although it is possible to assume that there are guarantees regarding the transfer of the LCD component at the same cost to both companies, it cannot be assumed that Philips has a priority allocation of volumes similar to LG. Just as in the Sony partnership described above, the partner - in this case LG - is the supplier of practically all the components necessary for production of the LCD panel, which results in higher transaction costs. 


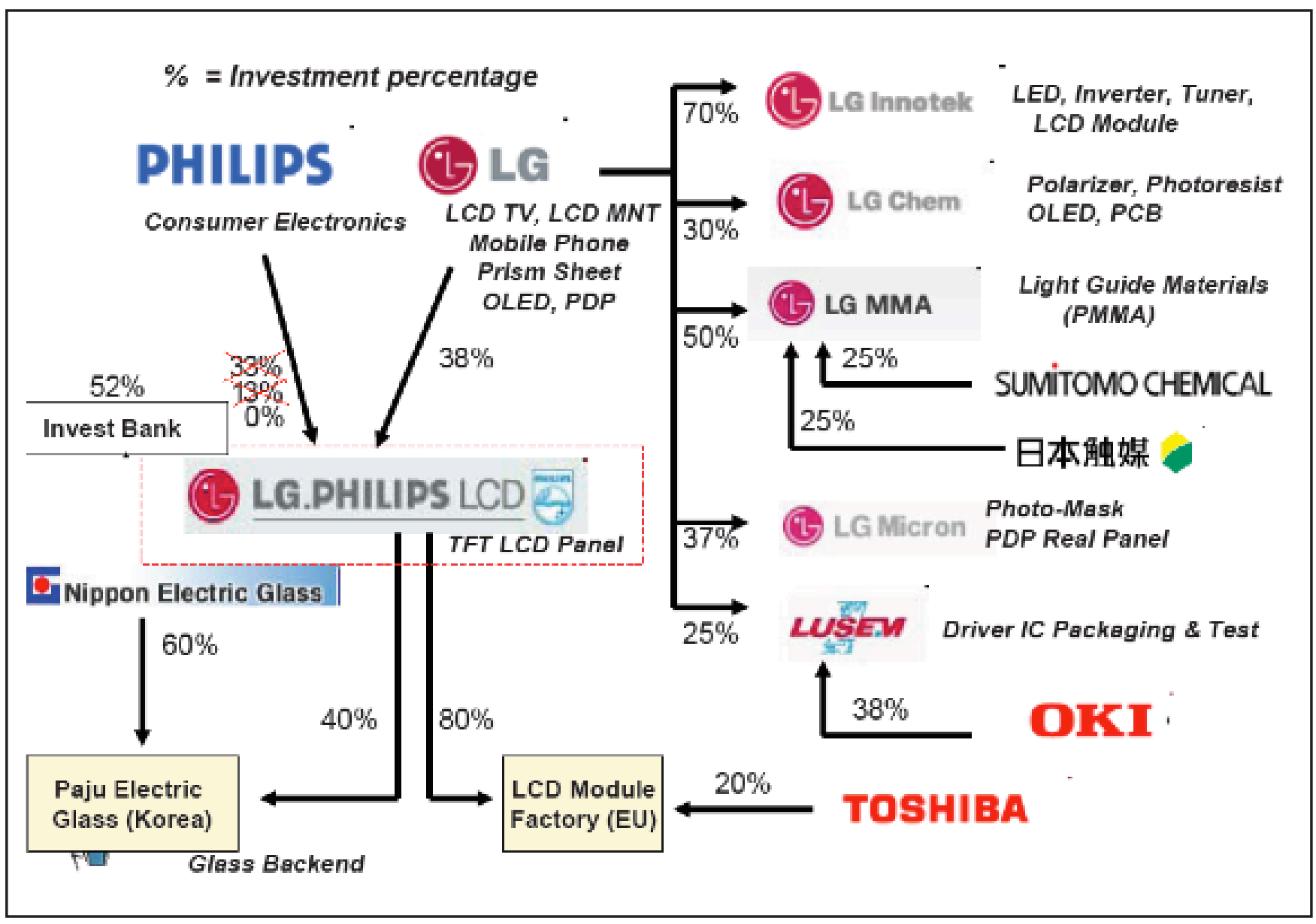

Figure 2: LG and Philips partnership/ Source: Display Search (2008)

Philips had the worst performance among the major suppliers of LCDs for televisions in the first quarter of that year, caused by a lack of direct control over the supply of LCD panels by its LGD subsidiary. This result, accompanied by weak seasonal conditions in the sales of LCD televisions, led to a $26 \%$ reduction in the dispatch of panels via the company's subsidiary in Taiwan to its LCD TV assembly plants worldwide. As a consequence, its position in the global market declined to third place, behind Sony.

It is worth highlighting the strategic positioning of Philips with regard to the de-verticalization of its production of LCD televisions. According to reports published by SNS Securities Research (2009), the Chief Executive Officer (CEO) of the company has for the past eight years been implementing a process for reducing risk exposure generally, particularly in the televisions line. These decisions led the company to a great level of production outsourcing.

\subsection{Philips: Make or Buy?}

Philips Global is a company that adopts a matrix model for its organizational structure and it replicates this same model in the various countries in which it operates. Based on actual data for 2008 , the Consumer Lifestyle unit, also called Philips consumer electronics, accounted for $65 \%$ of revenues from all units in Brazil. In this unit, television sets accounted for approximately $55 \%$ of all its revenue, of which $70 \%$ came from LCD televisions. So, the representativeness of this line in Philips' sales reached $25 \%$ of all its sales in 2008. In 2010, with the company stopping making television tubes, LCD televisions will represent about $30 \%$ of total revenue, which is mainly because it is a soccer World Cup year. 
According to RBT, competitive advantage is related to the exploitation of resources that are valuable, scarce and hard to imitate. In addition, the firm needs to be capable of exploiting this resource in an organized way in order to have a superior performance in the industry (Barney, 1999). We try to identify the perceptions of the Philips' executives with regard to the LCD panel as an organizational resource, based on the VRIO model.

In this sense, the Philips' executives considered $d$ the LCD panel as a valuable resource for the industry in which they operate, because it allowed the company to explore opportunities and contain threats in the business environment. The answers of all respondents converged in this sense, which corroborates the relevance of the panel, as shown in the previous topic.

Then, understanding of the scarcity attribute was checked, which was defined as the criterion that assesses the number of competitors who have a valuable resource. The responses converged on the understanding that the LCD panel was a scarce resource. The executives agreed that there are few panel supplier options in the market and that the same was true when the decision was made to outsource. The level of governance needed to obtain LCD panels was also checked. The executives indicated the need for intermediate levels of governance that, to a certain extent, indicate the difficulty in obtaining this resource. They believed that it is not possible to purchase the LCD panel at market governance levels, although they did not consider it compulsory, for example, to establish a strategic alliance of the joint venture kind.

Questions were also asked about the ability of imitating the resource, understood as the ease with which the competition can copy the valuable and scarce resource. Therefore, there would be a cost disadvantage in obtaining or developing it. Although there was no consensus, the vast majority of executives agreed that there are barriers to copying the resource. As seen in the previous section, the manufacturing of the panel is connected to the TV set design. In addition, these executives believe that it would be difficult to achieve a production level with a performance superior to that of the competitors and that this type of operation could take some time (around two years) to become adapted. We can see, therefore, that the company would need to develop the capability needed for production.
We also evaluated whether the processes of Philips are organized to support the exploitation of this valuable, scarce and costly to imitate resource. The executives were asked if, operationally, the company had the structu$r$, in the form of knowledge of the processes, necessary for producing the good; the existence of fixed assets was not assessed. The executives understood that the company had the knowledge it needed if it were to choose to produce the LCD panel internally. They also believe that achieving superior performance in the supply of LCD panels would enable the company to enjoy a sustainable competitive advantage.

To complement RBT, the case was analyzed using the Transaction Cost Theory (TCT). According to the Philips executives, the assets dedicated to the production of panels tend to be standardized. Within the terms of TCT, there are few specific assets earmarked for manufacturing panels. However, the project is exclusive, to the extent that the failure by the current partner to supply the panel would possibly lead to a breakdown in Philips production because it is highly unlikely it would find another supplier that would be able to replace the item.

In another dimension, information asymmetry, the high transaction costs can be seen. Those interviewed believe that it would be difficult to obtain relevant information from the supplier. The executives also understand that not all factors capable of generating effective safeguards for Philips were dealt with in the agreement, which could be related to limited rationality, as explained by the cognitive limitations of the human mind for considering all the preponderant factors when preparing a contract. However, they state that it is possible to establish an agreement that clearly specifies the performance standards required and the rules necessary for carrying out the transaction.

Another dimension of TCT is uncertainty related to the environment in which the transaction occurs. We sought to identify the difficulty in forecasting demand for the LCD panel resource. This factor is important because environments with a strong degree of uncertainty may suggest that one of the parties acts opportunistically and thus increase the transaction costs. The Philips' executives believe that any uncertainties that occur in this business do so at a reasonably high level. They also say that the environment is favorable to opportunistic behavior on the part of the supplier. 
The level of relationship between the parties was evaluated. The result of the interviews indicates that there is a certain level of collaboration in the search for a solution to problems. The executives believe that if there was clearly an unfavorable environment, companies would be willing to act in a collaborative manner, thereby seeking to reduce transaction costs.

In short, the LCD panel was considered as a potential source of competitive advantage for Philips, according to the understanding of the companies' executives with regard to the conceptual bases of RBT. In addition, according to TCT the purchase of the panel from a supplier proved to be a costly transaction, which supports the decision to internalize the operation.

\section{Final Considerations}

This study sought to assess the relationship between the outsourcing process and competitiveness, based on the Philips' case. Some disadvantages of outsourcing can be found in the model adopted by Philips: the probable loss of capabilities that are important for operating in the LCD television segment and the difficulty in creating and managing legal contracts. Unlike the partnership established by Philips, Sony tried to build a model with Samsung that allowed it to have greater participation and control over production processes. Sony's outsourcing model also suggests greater control over factors linked to managing contracts; since the company is heavily involved in the production process of its supplier, this increases the possibility of achieving greater transparency in those factors essential for supply. In this scenario, transactions are more likely to be carried out at the intermediate level of governance, as is the case with Sony and Samsung. From the perspective of transaction costs, there was considerable information asymmetry, uncertainty, limited rationality, impacted information and the potential for opportunism in the transaction studied. Philips would probably achieve lower costs if it were to seek another level of governance, having as examples both LG and Samsung, which are disputing the top place in the market through hierarchical governance.

The results of this work helped the company's executives in their decision-making about the company's operation in this segment. As reported in Valor Econômico (Economic Value, in Portuguese - Brazil) newspaper on 07/01/2010, Philips intends investing $R \$ 200$ million in local production of LCD screens during the first year of activity. It is expected that I million screens will be assembled during this period at its plant in Manaus. Over three years, the forecast is that Philips' total investment in manufacturing the LCD is likely to exceed $R \$ 720$ million, expanding the volume produced to 1.3 million LCD units in 2012 (Borges, 2010) .

The Philips case study, in addition to its practical relevance as depicted in the investments mentioned, has important academic implications. The article sought to explore the theoretical complementarity that exists between RBT and the transaction cost theory. The TCT approach is based on an economic bias and suggests short and medium term analyses of outsourcing processes, while the RBT approach, because it has a strategic bias, ends up suggesting longer term analyses, since it is concerned with future competitive positioning. The work can also be used in Operations and Supply Chain courses as a teaching case or as an example of an analysis of the makeor-buy trade-off.

\section{References}

AMIT, R; SCHOEMAKER, P (1993). "Strategic assets and organizational rent”. Strategic Management Journal, v. I4, n. I, p. 33-46.

BARDHAN, I.S.; MITHAS, S.; LIN (2007). "Performance impacts of strategy, information technology applications, and business process outsourcing in U.S. manufacturing plants". Production and Operations Management, v.16, n. 6, p. 747-762.

BARNEY, J (199I). "Firm resources and sustained competitive advantage”. Journal of Management, v. 17, p. 99-120.

BARNEY, J (1997). Gaining and Sustaining Competitive Advantage. Addison-Wesley: Reading, MA.

BARNEY, J (1999). "How a firm's capabilities affect boundary decisions”. Sloan Management Review, v. 40, n. 3, p. I37-145.

BORGES, A (2010). "Philips vai produzir LCD no Brasil". Valor Econômico, Rio de Janeiro-RJ, 0I/07/20I0. 
CANEZ, L.E.. PROBERT, D.; PLATTZ, K (2000). “Developing a framework for make-or-buy decisions". International Journal of Operations and Productions Management. Bradford: v. 20, n. II, p. I3I3.

CHANG, S. J. (2008). Sony vs. Samsung, the inside story of the electronics giants' battle for global supremacy. Ist edition. Singapore: Wiley \& Sons.

CHESBROUGH, H. W.; TEECE, D. J. (1996). When is virtual virtuous? Organizing for innovation. Harvard Business Review, January-February, pg.65-73.

COASE, R. (1937). "The nature of the firm". Economica, v. 4, p. 386-405.

DISPLAY SEARCH (2009). TV: Market and Panel Development. Available at http://www.displaysearch.com/ files/2008_January_TV_Market_and_Panel_Development_Trends.pdf (accessed I5 august 2009).

DOIG, S.; RITTER, R.C.; SPECKHALS, K.; WOOLSON, D (200I). "Has outsourcing gone too far?" McKinsey Q, n. 4, p.24-37.

DRTINA, R. E. (1994). "The outsourcing decision". Management Accounting. v. 75, p.56-62.

EISENHARDT, K.M.; MARTIN, J.A. (2000). "Dynamic capabilities: what are they?" Strategic Management Journal, Special Issue, v. 2I, p. ||105-II2I.

FINE, C.; WHITNEY, D. (1996) "Is the make-buy decision a core competence?" Working Paper, MIT Center for Technology, Policy and Industrial Development.

GFK - Growth from Knowledge. GVK Group online. Available at www.gfk.com (accessed I5 august 2009).

GHOSHAL, S.; MORAN, P. (1996). "Bad for practice: a critique of transaction cost theory". Academy of Management Journal, v. 21 , p. $48 I-510$.

GRAY, J.V.; ROTH, A.V, TOMLIN, B. (2008). "The influence of cost and quality priorities on the propensity to outsource production". Working paper, Fisher College of Business, Ohio State University, 2008.
HOLCOMB, T. R.; HITT, M. A. (2007). "Toward a model of strategic outsourcing”. Journal of Operations Management, v. 25 , n. 2 , p. $464-48$ I.

KLEIN, B.; CRAWFORD, R.A.; ALCHIAN A.A. (1978). "Vertical integration, appropriable rents, and the competitive contracting process". Journal of Law and Economics, v. 21, p. 297-326.

LANGLOIS, R.N.; ROBERTSON, P.L. (1995). Firms, Markets and Economic Change: A Dynamic Theory of Business Institutions, Routledge, London.

LEI, D.; HITT, M.A.; BETTIS, R. (1996). Dynamic core competences through meta-learning and strategic context. Journal of Management, v. 22, p. 549-596.

MCIVOR, R. (2008). "How the transaction cost and resource-based theories of the firm inform outsourcing evaluation”. Journal of Operations Management, v. 27, p. 45-63.

NOVAK, S.; STERN, S. (2008). "How does outsourcing affect performance dynamics? Evidence from the automobile industry". Management. Science, v. 54, v.12, p. 1963-1979.

PENROSE, E. (1959). The Theory of Growth of the Firm. Basil Blackwell: London.

PETERAF, M. (1993). "The cornerstones of competitive advantage: a resource-based view". Strategic Management Journal, v. 14, n. 3, p. 179-191.

PORTER, M.E. (1980). Competitive Strategy, Free Press, New York.

QUINN, B. J. E HILMER, F. G. (1994). "Strategic Outsourcing”, Sloan Management Review, Summer, pg. 43-55.

SNS SECURITIES RESEARCH. A New Bleeder in the Portfolio, available at https://www.snssecurities.nl/scripts/company/index.aspx?section $=$ Research \&fc $=$ ph\&alpha $=P \&$ displa $y=$ publications\&filename $=54746$ (accessed 15 April 2009).

STUCKEY; J.; WHITE, D. (1993). "When and when not to vertically integrate”. Sloan Management Review, v. 34, n. 3. 
TEECE, D.; PISANO, G.; SHUEN, A. (1997) "Dynamic capabilities and strategic management". Strategic Management Journal, v. 18, n. 7, p. 509-533.

WERNERFELT, B. (1984). "A resource-based view of the firm”. Strategic Management Journal, v. 5, n. 2, p. I7I-I80.

WILLIAMSON, O. (1975). Markets and Hierarchies, Analysis and Antitrust Implications: A Study in the Economics of Internal Organization. Free Press: New York.

WILLIAMSON, O. (1983). "Organizational innovation: the transaction cost approach". In: RONEN, J. (org.) Entrepreneurship. Lexington Books: Lexington, MA, p. I0I-I33.

WILLIAMSON, O (1979). "Transaction cost economics: the governance of contractual relations". Journal of Law and Economics, v. 22, p. 233-26I, 1979.

WITSVIEW - LCD Research Institution (2009). Panel Availability. Available at http://www.witsview.com/Productlnfo/PanelAvailability.aspx (accessed 03 September 2009).

WOOLLACOTT, E. (1998). "Cost-cutting still main goal of outsourcing, survey finds". Computerworld, Availiable at http://computerworld.co.nz/news.nsf/mgmt/IB6F4IDD0F 99B7DBCC257I4500I0BIC3 (April 3 2006).

WRIGHT, P.; KROLL, M. J. e PARNELL, J. (1998). Strategic Management: concepts and cases. NJ: Prentice-Hall.

ZAJAC E.J.; OLSEN, C.P. (1993). "From transaction cost to transactional value analysis: implications for the study of interorganizational strategies". Journal of Management Studies, v. 30, p. $13 \mid-145$. 
J. Technol. Manag. Innov. 20II,Volume 6, Issue 2 